\title{
The Need for Total Quality Management Implementation at a University College: A Descriptive Approach
}

\author{
Mukole Kongolo \\ The Archbishop James University College (AJUCO) \\ Private Bag 466, Songea, Tanzania \\ E-mail: kongolo@ajuco.ac.tz
}

Received: Oct. 29, 2018 Accepted: Nov. 23, 2018 Online published: Dec. 5, 2018

doi:10.5296/ijhrs.v8i4.14005 URL: https://doi.org/10.5296/ijhrs.v8i4.14005

\begin{abstract}
The main objective of this paper is to highlight the importance of TQM as an important tool in solving management issues that have been subjected to university college. A descriptive approach was followed in presenting this paper. The paper deals with TQM approaches in resolving issues related to management weaknesses at the university college level. This is a critical issue from the various institutional viewpoints. The paper is a result of a careful evaluation and assessment of the passed approach to management at various university colleges. A new way in which management of the university college should work to improve approaches to teaching, learning and research needs to be initiated through TQM implementation. The results suggest that TQM approach has the potential to revolutionalise the system of education at the University college as institutions of higher education.
\end{abstract}

Keywords: total quality management, quality performance, improved management, business excellence, service delivery, college education system

\section{Introduction}

A university college is a higher education institution that provides tertiary education but does not have full or independent university status. In many countries, a university college is often part of a larger university. The term "University College" is used in different ways in different countries. For instance, the term "University College" was used in Australia to refer to higher education institutions that were like universities, but lacked full autonomy. University colleges existing today generally cater for specific subjects, such as Theology, or the Arts (Velasco, (2015). The term University college was used in Belgium to refer to 
state-funded institutions of higher education that are not universities, and which belong to one of the three Communities of Belgium. They can issue academic or non-academic Bachelor's degrees or academic Master's degrees, but are not allowed to conduct research. Their degrees are not the same as those issued by Universities (Shariffuddin \& Razali, 2016). A University College in Canada means three things: (a) a degree-granting institution; (b) an institution offering a university-level coursework; and (c) a constituent organization (college) of a university. The term University College is mainly used by institutions that do not have full university status, but which do extensive teaching at degree level (Velosco, 2015).

Higher education institutions in general have been undergoing a process of change similar to what business organisations have undergone for many reasons, namely the demands from industry, increased quality competition, quest among academics, information-age mind set of the students community, are some of these reasons for change (Marginson, 2011). To ensure that a university college is able to deal with market and technological changes coupled with global requirements, it is important to use appropriate curricula, course materials and teaching methodologies that are not only up-to-date, but also effective from learner's point of view (Jung and Wang, 2006). The exponential growth of knowledge in other domains is left with faculty members to continuously evaluate themselves and improve upon their effectiveness (Hîncu, 2011). Higher education imparts in-depth knowledge and understanding of the various issues related to social, economic, political and environmental so as to advance the students to new frontiers of knowledge in different aspects of life (Demirbag et al., 2006). Higher Education develops student's ability to question and seek truth while making him/her competent to critique on contemporary issues (Jessop, 2013). It broadens the intellectual powers of the individual within a narrow specialization, but also gives him/her a wider perspective of the world around (Sudha, 2013). From the literature point of view, the concept of higher education describes the production of qualified human resources, training for research career, efficient management of teaching profession and a way of extending life chances (Seth and Tripathi, 2005). From the view point of the paper, it can be noticed that all the above concepts are not exclusive, rather they are integrated by describing the overall aspect of a university college as higher education institution. In other words, the activities of a university college are based on teaching, learning, research, and community work, which form the core functions of higher education (Jessop, 2016).

Various empirical studies have examined the impact of TQM practices on both performance and relationships in various institutions/organisations (Powell, 1995; Ahire and Golhar, 1996; Motwani, 2001; Montes et al., 2003; Brah and Lim, 2006; Kapuge and Smith, 2007). In contrast to these studies, this paper looks at the ways in which TQM can be implemented to cement working relationships in different ways at university college. A simple approach to TQM practices has been adopted to deal with services delivery at the university college. It is hoped that the approach used will go a long way to assist the institution developing an integrated TQM model of issues that need to be changed effectively and successfully. As such, the model could be used as the basis for future uses in other related circumstances. Given that most TQM studies have been carried out in developed countries, the present paper contributes to empirical literature on TQM practices and implementation (Hellsten and Klefsjo, 2000; 
Vinni, 2011) by fostering its impact on university college. This paper complement the body of literature by providing new empirical insights into the relationship between the effects of TQM practices on management, institutional performances and service delivery at university college.

\subsection{The Problem}

The majority of university colleges have been subjected to different types of management and administration. This has caused not only more harm in the academic staff, teaching and learning programmes, but also in the whole educational system. In addition, the structures in places were not well respected, as both Heads of Departments (HODs) and Deans could not perform their duties well to the expectation of the stakeholders. This has invariably led to the issue of total quality management (TQM) and effective service delivery by university college. Although there is a considerable literature on TQM that provide general investigation of TQM practices implementation in the higher education institutions in developed nations, there is however very few existing literature in developing nations point of views (Powel, 1995; Prajogo, 2005). Although TQM practices are applied differently in higher education, it is interesting to juxtapose and compare the TQM practices implemented and the relationship of these practices in the higher education service delivery (Kenneth, 2005; Geotsch and Davis, 1997; Sureshchandar et al, 2001; Lee et al, 2003; Ahmed and Sushil, 2008). Correctly managed TQM towards achieving maximum service delivery is strategically and tactically important for obtaining a competitive advantage in higher education (Cheah et al, 2009). In order to provide university college with practical assistance in TQM practices, this paper examines its impact on service delivery. Given the above background, the main objective of this paper was to theoretically conceptualize TQM implementation at university college. The paper builds upon the foundation of the major literature on TQM practices and implementation. It attempts to provide holistic perspective of TQM practices implementation to promote excellence in education at university college. The rest of the paper is organised as follows: section 2 describes the methodology and information used; section 3 defines TQM and quality models in higher education; section 4 concludes.

\subsection{Objectives}

The main objective of this paper is to describe the importance of TQM as an important management tool for change of environment at the University College. Specifically, the paper is intended to: (a) explore the required TQM techniques for implementation at university college to support the change; and (b) take action on its success regarding various components involved of university college core activities.

\section{Methodology}

\subsection{Design and Information Used}

The fundamental reason for this paper is to explore the various ways in which TQM can be used to improve management and other related service to contributes to the overall development of the university college. In order to achieve this, the influences of the different core functions were considered together with other factors such administration and finance. 
University college traditional functions of imparting knowledge and human capital development together with teaching staff motivation have been the most important contributing factors that the TQM techniques tried to improve. By considering these factors, the paper extends on previous studies in supporting more general claims about the relative importance of university activities in influencing development outcomes of both staff and students (Goldstein and Renault 2004). The paper is based on information collected through various ways. Considering the fact that there can be number of sources to gather information, the methodology adopted represents relatively a cost effective approach. The first step involved a thorough review of related literatures such as published and unpublished reports, TQM studies, articles, policy documents, as well as reports of programs, organisations. In other words, the information for this paper was obtained through a document methods, with secondary sources of information being used. Although it might be argued that the primary secondary distinction is blurred, the difference is clear in so far as primary sources are concerned to be the original written materials of the author's own experiences and observations. Secondary sources are the materials derived from someone else as the original sources. The examination of the different sources of information assisted in looking at the contribution of university college to national economic development. The paper methodology was carefully designed to maximize the use of the available qualitative information

\section{Total Quality Management}

Total Quality Management (TQM) has been used as a management tool by many business organizations worldwide. To understand the meaning of "Total Quality Management", we need first to know what does "Quality" mean? Quality refers to a parameter which decides the superiority or inferiority of a product or service (Kongolo and Dlamini, 2014; ASQ, 2018). The Quality can be defined as an attribute which differentiates a product or service from its competitors (Sureshchandar et al, 2001). Quality plays an essential role in every business (Geotsch and Davis, 1997). Business marketers need to emphasise on quality of their brands over quantity to survive the cut throat competition (Juneja, 2008). Total Quality management can be defined as a continuous effort by the management as well as employees of organization to ensure long term customer loyalty and customer satisfaction (Juneja, 2008). Total quality management ensures that every single employee is working towards the improvement of work culture, processes, services, systems and so on to ensure long term (Juneja, 2008). The history of quality is a concept of the $20^{\text {th }}$ century that has its roots in the organisations, industry and management. Table 1 provides order of quality movement from $1900-1990$.

Table 1 . The chronology of quality movement

\begin{tabular}{l|l}
\hline Year & Description \\
\hline Pre 1900 & Quality as integral element of craftsmanship \\
\hline From 1900-1920 & Quality control by foreman \\
\hline From 1920-1940 & Inspection based on quality control \\
\hline From 1940-1960 & Statistical Process Control \\
\hline From 1960-1980 & Quality assurance and Total Quality Control \\
\hline From 1980-1990 & Total Quality Management \\
\hline From 1990 to Present & $\begin{array}{l}\text { TQM, the way of continuous improvement, organization-wide quality } \\
\text { management }\end{array}$ \\
\hline
\end{tabular}


Sudha, (2013).

Quality became an issue with the advent of industrialisation and adoption of new scientific approach to management based on division of labour (Sudha, 2013). With mass-production and breaking down of the work into smaller tasks handled by machines, this reduced the role of workers for self checking of quality. As a lecturer, HOD, Dean, Principal and policy maker in education we should all worry about quality of teaching, programmes, management and institution as a whole, because of competition, customer (students) satisfaction, level of standards, accountability, motivation and improvement of employee morale, credibility, prestige and status, image and visibility. Total Quality Management (TQM) is a management approach to achieving long-term success through customer satisfaction. The quality of management is a very important aspect of any university that respects itself in terms of research, teaching, learning, work control, institutional planning and market, all being the target for improvement in quality services for the benefits of the clients (Todorut, 2013). In a TQM effort, all members of the institution participate in improving processes, products, services, and the culture in which they work (ASQ, 2018). Therefore, TQM is seen as a management system for a customer-focused institution that involves all employees in a continual improvement (Kenneth, 2005). It uses strategy, data, and effective communications to integrate the quality discipline into the culture and activities of the institution (ASQ, 2018). According to ASQ (2018), there are 8 principles of total quality management, namely: Customer-focused, Total employee involvement, Process-centered, Integrated system, Strategic and systematic approach, Continual improvement, Fact-based decision making and Communications. These principles are very essential for TQM that many organizations should define them in some format, as a set of core values and principles on which the organization is to operate.

\subsection{Models of Quality in Higher Education}

TQM models based on quality in higher education generally involve a number of principles such as teamwork, top management leadership, customer focus, employee involvement, continuous improvement, quality teaching/training (Lee et al, 2003; Todorut, 2013). For higher education institution, TQM is a vision that can be achieved through long-term planning, by implementing annual quality plans which gradually lead towards the fulfillment of the vision (Murad and Rajesh, 2010). Application of TQM concepts is one of such measures, which will go a long way in revolutionizing the higher education system (Todorut, 2013). The paper attempts to theoretically conceptualize TQM in higher education. TQM helps create a conducive climate within the institution in terms of creative and efficient use of resources which can give the staff confidence in management (Kongolo and Dlamini, 2014). An introduction of the principles of TQM in a university environment depends on the existence of an adequate quality culture of the entire staff. The institutional culture from the universities affects the application procedures in the context of quality strategies, although it does not appear directly but through its consequences (Todorut, 2013).

The culture integrates values, beliefs and behavior norms that have proved to be benefic for the university in its past and confer personality, fame and at the same time shape to the 
student life that enhance the pleasure to learn. This enhancement matters a lot when it comes to appreciate those who have studied and have graduated from those universities (Sangeeta et al., 2004). University's culture represents its genetic environment, its unwritten but mandatory regulation. It is conservative through its nature and will oppose any innovation or major changes of management. And still, due to the major changes of our society even Harvard University is submitted to a continuous adaptation process which is done through a managerial system and through an adequate quality policy. Here where excellence in quality has represented and still represents the essence of university life. Following Todorut (2013), the re-establishment of a normal balance between the management of quality and institutional culture can be done through: (a) the implementation of new ways of thinking; (b) the implementation of strategic management; and (c) the implementation of quality management. Product dimensions of quality in higher education is given in Table 2.

Table 2. Product dimensions of quality in higher education

\begin{tabular}{l|l}
\hline Dimension & Definition in higher education \\
\hline Performance & Primary knowledge/skills required for graduates \\
\hline Features & Secondary/Supplementary knowledge and skills \\
\hline Reliability & $\begin{array}{l}\text { The extent to which knowledge/skills learned are correct, accurate } \\
\text { and up to date }\end{array}$ \\
\hline Conformance & $\begin{array}{l}\text { The degree to which an institutional programme /course meets } \\
\text { established standards, plans and promises }\end{array}$ \\
\hline Durability & The depth of learning \\
\hline Serviceability & How well an institution handles customer semplaints? \\
\hline
\end{tabular}

Sudha, (2013).

The dimensions of quality in higher education quality was originally developed following the manufacturing industry standards (Sudha, 2013). In terms of higher education, the adoption of quality control was superficial and was replaced by the exercise of academic freedom (Largosen, et el, 2004). The prevailing culture of universities is often based on individual autonomy, and as a result, it was well respected (Sangeeta et al., 2004). Therefore, it is often difficult to apply the features of quality to higher education institutions given the fact that quality requires team work (Boaden and Dale, 1992). However, the quality of higher education is very important for stakeholders which include students, academic and admin staff, funding bodies, and the community at large (Srikanthan and Dalrymple, 2003). The most commonly used dimensions of quality in higher education are product and service (Sudha, 2013).

\subsection{Dimensions of Service Quality in Higher Education}

The service quality dimension is perhaps more unlikely to education processes. It is unlike goods and services that can be consumed as long as the production process continues. This is because the consumer is an integral part of the production process. Therefore, in higher education, this is more related to teaching and learning situations which describe services. Parasuraman et el. (1995) identified the following dimensions of service quality (Table 3). 
Table 3. Service quality dimensions in higher education

\begin{tabular}{l|l}
\hline \multicolumn{1}{c|}{ Dimensions } & Definition in higher education \\
\hline Responsiveness & Willing and readiness of staff to help students \\
\hline Reliability & $\begin{array}{l}\text { The degree to which education is correct, accurate and up to } \\
\text { date }\end{array}$ \\
\hline Understanding customers & Understanding students and their needs \\
\hline Access & The extent to which staff are available for guidance and advice \\
\hline Competence & $\begin{array}{l}\text { The theoretical and practical knowledge of staff and other } \\
\text { presentation skills }\end{array}$ \\
\hline Courtesy & Emotive and positive attitude towards students \\
\hline Communication & How well the students and lecturers communicate in the class \\
\hline Credibility & The degree of trustworthiness of institution \\
\hline Security & Confidentiality of information \\
\hline Tangible & State, sufficiency and availability of equipment and facilities \\
\hline Performance & Primary knowledge/skills required for graduates \\
\hline Completeness & Supplementary knowledge/skills, use of computer \\
\hline
\end{tabular}

Source: Sudha (2013).

\subsection{TQM and Customer Satisfaction}

Following Bank (2000), total quality management focuses on the requirement of the customer. Customer satisfaction leads to positive results for an institution such as retention, positive word of mouth and improved financial performance (Ahmed and Sushil, 2008). According to Kongolo and Dlamini, (2014), in a total-quality setting, quality is defined by the customer. Geotsch and Davis (1997) asserts that the customer must be the organization se reliable customers are the most important customers and, customer satisfaction is ensured by producing high-quality results/products. Quality institutions require that employees demonstrate customer-service skills, self-direction, development and team-development skills. Focus on customer satisfaction is critical, and it often requires a continued improvement in the business (Heinemann and Judge, 2003).

\section{Conclusions}

Total Quality Management (TQM) has been used as a management tool by many business organizations worldwide. TQM can be described as a continuous effort by the management as well as employees of organization to ensure long term customer loyalty and customer satisfaction (Juneja, 2008; ASQ, 2018). TQM ensures that every single member of the institution works towards the improvement of work culture, processes, services, systems and so on to ensure long term (Juneja, 2008). Quality refers to a parameter which decides the superiority or inferiority of a product or service (Kongolo and Dlamini, 20148) The Quality can be defined as an attribute which differentiates a product or service from its competitors (Sureshchandar et al, 2001). Quality plays an essential role in every business (Geotsch and Davis, 1997). Business marketers need to emphasise on quality of their brands over quantity to survive the cut throat competition (Juneja, 2008). Strong evidence points on the potential 
for TQM in regenerating needed results. The results of the paper suggest that the implementation of TQM approach as management tool helped generate competitive results for this paper. TQM helps in achieving high quality services, delivery of competitive services on time, and at competitive prices. TQM is a common factor with the potential to shape the strategies of university college as a higher educational institution in attempting to satisfy various needs of its stakeholders. It promotes the culture of working together for common good of the institution, promotes mutual respect between management and staff, allows better control of the processes in designing, planning, distribution with greater flexibility. TQM leverages, consolidates the motivation and creativity of the staff, leading to greater potential for innovation, allowing a better control of processes in planning, designing and distribution (Hanson, 2003).

\section{References}

Ahire, L., \& Golhar, Y. (1996). Quality management in large vs small firms. Journal of Small Business Management, 34(2), 1-11.

Ahmed, N. U., \& Sushil, K. S. (2008). TQM in a virtual organization: Issues and strategies. International Journal of Management Enterprise Development, 5, 541-553. https://doi.org/10.1504/IJMED.2008.019082

AJUCO Principal. (2018). Report to Tanzanian Commission for Universities (TCU), Songea, 2018.

AJUCO web site. http://www.ajuco.ac.tz/.

ASQ. (2018). What is total quality management (TQM)? American Society for Quality http://asq.org/learn-about-quality/total-quality-management/overview/overview.html

Bank, J. (2000). The Essence of Total Quality Management, 2nd ed. Harlow, Pearson Education Ltd.

Boaden, R. J., \& Dale, B. G. (1992). Team work in Services: Quality circles by another name? International Journal of Service Industry Management, 17(3), 126-136.

Brah, S., \& Lim, H. (2006). The effects of technology and TQM on the performance of logistics companies. International Journal of Physical Distribution \& Logistics Management, 36(3), 192-209. https://doi.org/10.1108/09600030610661796

Cheah, W. C., Ooi, K. B., Tech, P. L., Chong, A. Y., \& Yong, C. C. (2009). Total Quality Management and Knowledge Sharing: Comparing Malaysiaees Manufacturing and Service $\begin{array}{lllll}\text { Organizations. Journal of Applied } & \text { Sciences, } & 9, & 1422-1431 .\end{array}$ https://doi.org/10.3923/jas.2009.1422.1431

Demirbag, M., Tatoglu, E., Tekinkus, M., \& Zaim, S. (2006). An analysis of the relationship between TQM implementation and organizational performance: evidence from Turkish SMEs. Journal of Manufacturing Technology Management, 17(6), 829-47. https://doi.org/10.1108/17410380610678828 
Goetsch, L. D., \& Davis, B. S. (1997). Introduction to Total Quality. Quality Management for Production Processing and Services, 2nd Ed. New Jersey, Prentice Hall.

Goldstein, H. A., \& Renault, C. S. (2004). Contributions of universities to regional economic development: A quasi experimental approach. Regional Studies, 38(7), 733-746. https://doi.org/10.1080/0034340042000265232

Hanson, J. (2003). Total Quality Management-Aspects of Implementation and Perormance, Lulea University of Technology, Department of Business Administration and Social Science, pp. 197-201.

Heinemann, G. H., \& Judge, A. T. (2003). Staffing Organizations: Middleton W1 McGraw-Hill.

Hellsten, H., \& Klefsjo, B. (2000). TQM as management system consisting of values, tehniques, and tools, The TQM Magazine, 12(4), 238-244. https://doi.org/10.1108/09544780010325822

Hîncu, D. (2011). The Positioning of Universities in Collaborative Models as Clusters in a Knowledge Based Economy. The Amfiteatru Economic Journal, 13(30), 14-19.

Jessop, B. (2013). Revisiting the Regulation Approach: Critical Reflections on the Contradictions, Dilemmas, Fixes, and Crisis Dynamics of Growth Regimes. Capital \& Class 37(1), 5-24. https://doi.org/10.1177/0309816812472968

Jessop, B. (2016). Putting higher education in its place in (East Asian) political economy, Comparative Education, 52(1), 8-25. https://doi.org/10.1080/03050068.2015.1128659

Juneja, P. (2008). Total Quality Management Meaning and Important Concepts. ManagementStudyGuide.com. https://managementstudyguide.com/portal/about-us

Jung, J., \& Wang, Y. (2006). Relationship between total quality management (TQM) and continuous improvement of international project management (CIIPM). Technovation, 26(5\&6), 716-22. https://doi.org/10.1016/j.technovation.2006.01.003

Kapuge, A., \& Smith, M. (2007). Management practices and performance reporting in the SriLankan apparel sector. Managerial Auditing Journal, 22(3), 303-18. https://doi.org/10.1108/02686900710733161

Kenneth, R. H. (2005). Project Quality Management: Why, What and How. Fort Lauderdale, Florida: J. Ross Publishing. p. 41. ISBN 1-932159-48-7.

Kongolo, M., \& Dlamini, D. F., (2014). Impact of Total Quality Management (TQM) on Service Delivery in Swaziland's Sugar Industry. International Journal of Operations and Logistics Management, 3(2), 158-169.

Largosen, S., Seyed, H. R., \& Leitner, M. (2004). Examination of dimensions of Quality in Higher Education, Quality Assurance in Education, 12(2), 61-69. https://doi.org/10.1108/09684880410536431 
Lee, S. M., Rho, B. H., \& Lee, S. G. (2003). Impact of malcolm baldrige national quality award criteria on organizational quality performance. International Journal of Production Research, 41, 2003-2020. https://doi.org/10.1080/0020754031000077329

Marginson, S. (2011). Higher Education in East Asia and Singapore: Rise of the Confucian Model. Higher Education, 61(5), 587-611. https://doi.org/10.1007/s10734-010-9384-9

Montes, M., Jover, V., \& Fernandez, M. (2003). Factors affecting the relationship between total quality management and organizational performance. International Journal of Quality \& Reliability Management, 20(2), 189-209. https://doi.org/10.1108/02656710310456617

Motwani, J. (2001). Critical factors and performance measures of TQM. The TQM Magazine, 13(4), 292-300. https://doi.org/10.1108/13683040010362300

Murad, A., \& Rajesh, K. (2010). Implementation of total Quality Management in Higher Education. Asian Journal of Business Management, 2(1), 9-16.

Parasuraman, A., Zeithami, V. A., \& Berry, L. L. (1995). A Conceptual Model of Service Quality and its implications for future research, Journal of Marketing, 49, 41-50. https://doi.org/10.1177/002224298504900403

Powel, C. (1995). Total Quality Management as Competitive Advantage. Strategic Management Journal, 16(1).

Prajogo, D. I. (2005). The comparative analysis of TQM practices and quality performance between manufacturing and service firms. Int. J. Service Ind. Manage, 16, 217-228. https://doi.org/10.1108/09564230510601378

Sangeeta, S., Banwet, D. K., \& Karunes, S. (2004). Conceptualising total quality management in higher education. The TQM Magazine, 16(2), 145-159. https://doi.org/10.1108/09544780410523044

Seth, D., \& Tripathi, D. (2005). Relationship between TQM and TPM implementation factors and business performance of manufacturing industry in an Indian context. International Journal of Quality \& Reliability Management, 22(3), 256-77. https://doi.org/10.1108/02656710510582480

Srikanthan, G., \& Dalrymple, J. (2003). Developing alternative perspectives for quality in higher education. International Journal of Education Management, 17(3), 126-136. https://doi.org/10.1108/09513540310467804

Sudha, T. (2013). Total quality management in higher education institutions. International Journal of Social Science \& Interdisciplinary Research, 2(6), 121- 132

Sureshchandar, G. S., Chandrasekharan, R., \& Anantharaman, R. N. (2001). A conceptual model for total quality management in service organizations. Total quality management, 12(3), 343-63. https://doi.org/10.1080/09544120120034492

Todorut, A.V. (2013). The need of Total Quality Management in higher education. Procedia Social and Behavioral Sciences 83, 1105 - 1110. 2nd World Conference on Educational 
Technology Researches WCETR2012. https://doi.org/10.1016/j.sbspro.2013.06.207

Vinni, R. (2011). Total Quality Management and paradigms of public administration, International Public Review, 8(1), 15-23. Retrieved from http: //www-sre. wu-wien.ac.at /ersa/ersaconfs/ersa04/ PDF/347.pdf, accessing October 19th, 2011

\section{Copyright Disclaimer}

Copyright for this article is retained by the author(s), with first publication rights granted to the journal.

This is an open-access article distributed under the terms and conditions of the Creative Commons Attribution license (http://creativecommons.org/licenses/by/4.0/). 